\title{
ANALISIS PEL AKSANAAN PEMBELAJARAN SENTRA BALOK PADA ANAK USIA 5-6 TAHUN
}

\author{
Sumariati Ode Alumu1, Farida Samad ${ }^{2}$, Rita Samad ${ }^{3}$ \\ Universitas Khairun \\ Fakultas Keguruan Dan Ilmu Pendidikan \\ Jl.Bandara Sultan Babulla Kota Ternate Utara, Kode Pos 53 Ternate 97728 \\ Telepon (0921)3110905-Faksimili 0921-3110901 \\ Email: sumariati240397@gmail.com1, Faridasamad81@gmail.com², \\ ritasamad5@gmail.com³
}

\begin{abstract}
Abstrak: Sentra balok merupakan sentra yang disediakan bagi pendidikan anak usia dini. Pada zona balok tersedia beragam jenis dan ukuran yang disertai aksesoris pendukung alat main peran. Melalui sentra balok anak-anak belajar mengenal bentuk, ukuran, konsep ruang, klasfikasi, team work, mengembangkan imajinasi, dan menghargai pendapat orang lain. Penelitian ini bertujuan menganalisis pelaksanaan pembelajaran sentra balok anak usia 5-6 tahun. Dalam pelaksanaan pembelajaran sentra balok ketika anak bermain balok guru memberikan motivasi dan bantuan pada anak yang membutuhkan serta melakukan penilaian. Evaluasi pembelajaran menggunakan penilaian berupa hasil karya anak. Dalam kajian ini penulis menggunakan metode literatur dengan serangkaian kegiatan pengumpulan data pustaka, buku-buku, serta tulisan yang terkait dengan judul penelitian. Selain itu, sentra balok juga dapat mengoptimalkan daya fikir, daya cipta, dan kreaktifitas serta mampu mengembangkan daya imajinasi. Dalam sentra balok terdapat 4 (empat) pijakan, yaitu : 1) pijakan lingkungan sebelum main, 2) pijakan sebelum main, 3) pijakan saat main, 4) pijakan sesudah main. Hasil Pembelajaran sentra balok aktifitas anak dapat meningkatkan 6 aspek yakni nilai agama moral, fisk motorik, kognitif, sosial emosional, bahasa dan seni.
\end{abstract}

Kata Kunci: Pembelajaran, sentra balok anak usia dini

Abstract: Block center is a center provided for early childhood education. There are various types and sizes, along with supporting accessories and role playing tools. Through the block center, children learn many things such as recognizing shapes, sizes, spatial concepts, classification, team work, developing imagination, and respecting others opinion. This study aims to analyze the implementation of block center learning in children aged 5-6 years. When children play with blocks, the teacher provides motivation and assistance to children who need it and makes assessments in block center learning. Learning evaluation uses an assessment in the form of children's work. The research method used the literature method with some activities conducted such as collecting library data, books, and writings related to the research problems. In addition, it also optimizes thinking ability, creativity, and creativity and developing imagination. In block center there are 4 (four) steps, namely: 1) environmental footing before playing, 2) stepping before playing, 3) stepping when playing, 4) stepping after playing. The results showed that children's activity in this center can improve 6 aspects, namely moral religion values, motor physics, cognitive, social emotional, language and art.

Key words: Learning, Early Childhood Center Dlocks

\section{A. Pendahuluan}

Anak usia dini adalah idividu yang mengalami proses pertumbuhan dan perkembangan yang sangat pesat, anak usia dini rentang usia yang sangat berharga dibanding usia selanjutnya karena perkembangan kecerdasannya sangat luar biasa. Usia tersebut merupakan fase kehidupan yang unik, dan berada pada masa proses 
perubahan berupa pertumbuhan, perkembangan, pematangan, dan penyempurnaan, baik dalam aspek jasmani maupun rohaninya yang berlangsung seumur hidup, serta bertahap dan berkesinambungan. Setiap anak memiliki karakteristik perkembangan yang berbeda-beda, yaitu dalam proses utama perkembengan anak merupakan hal yang paling penting kehidupan anak. Menerut Azhari (2017:287), pendidikan anak usia dini merupakan salah satu bentuk satuan pendidikan pada jenjang pendidikan anak usia dini yang pada hakekatnya adalah pendidikan yang diselenggarakan dengan tujuan untuk menfasilitasi pertumbuhan dan perkembangan anak secarah menyeluruh atau menekan pada pekembangan seluruh aspek kepribadian anak.

Palupi (2019) menjelaskan BCCT adalah singkatan dari Beyond, Center, dan Circle time. Metode pembelajaran ini di Indonesia dipopulerkan dengan istilah SELING (sentra dan lingkaran). Metode ini merupakan pengembangan dari metode Montessori, High Scope dan Regio Emilio yang dikembangkan oleh Creativ Center for Childhhood Research and training (CCCRT) Florida, USA. BCCT Merupakan konsep belajar dimana guru-guru menghadirkan dunia nyata dalam kelas dan mendorong siswa membuat hubungan antara pengetahuan yang dimiliki dengan penerapannya dalam kehidupan sehari-hari. Hasilnya adalah siswa memperoleh pengetahuan dan keterampilan dari konteks yang terbatas, sedikit demi sedikit dan dari proses mencoba sendiri sebagai bekal untuk memecahkan masalah dalam kehidupannya.

Pembelajaran yang telah dijadikan sebagai landasan ataupun acuan dalam pembelajaran anak usia dini yaitu pembelajaran sentra. Dalam pembelajaran tersebut sangat mempengaruhi 6 aspek perkembangan untuk anak usia dini yaitu: nilai agama dan moral, dimana pembelajaran sentra balok anak belajar saling mengahargai, berbagi dengan teman sesama sebaya dalam bermain balok, pada pembelajaran sentra balok juga meningkatkan kemampuan fisik motorik anak yaitu anak menggunakan jari jemarinya dalam menyusun balok membentuk suatu bangun yang anak inginkan, kemampuan kognitif anak juga dapat di kembangkan melalui pembelajaran sentra balok anak dapat bereksplorasi dapat mengembangkan pengetahuanya sendiri anak berpikir untuk menciptakan hal-hal baru dari balok-balok tersebut.

Pembelajaran sentra balok perkembangan kemampuan sosial emosional dapat dilihat dari interaksi anak dengan teman sebaya dan interaksi antara anak dengan guru, perkembangan bahasa anak terlihat dari bagaimana anak berkomunikasi dengan teman dan guru selama proses pembelajaran, sedangkan untuk perkembangan seni anak dapat meningkatkan kreaktivitas dengan memberikan kesempatan pada anak bereksplorasi, bermain, dan menemukan bahwa dalam kegitannya akan membantunya memecahkan masalah dan mempelajari dalam memahami keahlian-keahlian baru dalam sentra anak dapat memanipulasi onbjek yang disediakan di sentra-sentra untuk mengembangkan percakapan, bermain, dan belajar sesuai tingkatan dan langkahlangkah yang diinginkan seperti sentra persiapan, sentra bahan alam, sentra imtaq, sentra seni, sentra main peran, dan sentra balok.

Menurut Retno dan Wismiarti dalam Fitriani dan Rohita (2019:3-4), sentra mengandung makna "setiap kegiatan di semua sentra yang disediakan memiliki titik pusat (centre point), yang semuanya mengacu pada tujuan pembelajaran." Pendekatan sentra dan lingkaran adalah pendekatan penyelenggaraan pendidikan bagi anak usia dini yang berfokus pada anak dimana dalam proses pembelajaran berpusat di sentra main dan saat anak dalam lingkaran. terdapat empat jenis pijakan (scaffolding) dalam pelaksanaan kegiatan bermain di sentra dan digunakan untuk mendukung perkembangan anak, yaitu (1) pijakan lingkungan main ; (2) pijakan sebelum main; (3) pijakan selama main; dah (4) pijakan setelah main. Keempat jenis pijakan ini harus dilaksanakan oleh pendidik untuk menciptakan kegiatan yang bermakna melalui pembelajaran sentra. 


\section{B. Metode Penelitian}

Metode yang digunakan dalam penelitian ini dengan pendekatan studi literature (library reseach) Menurut Zeed Mestika, dalam Zahriyani (2020:4), metode penelitian dengan penedekatan studi literature merupakan penelitian yang serangkaian dengan metode pengumpulan data pustaka, buku-buku, serta tulisan yang tersebut, dari perpustakaan, buku-buku, serta tulisan yang terkait dengan judul penelitian tersebut, dari perpustakaan kamus online (contoh wikipedia) dan internet yang dapat memperkuat naska yang akan dipublikasikan.

C. Pembahasan

\section{Pembelajaran Anak Usia Dini}

Anurrahaman (2012:33), dalam aktivitas kehidupan manusia sehari-hari hampir tidak perna dapat terlepas dari kegiatan belajar, baik ketika seseorang melaksanakan aktivitas sendiri, maupun di dalam suatu kelompok tertentu. Dipahami atau pun tidak dipahami, sesungguhnya sebagian besar aktivitas di dalam kehidupan sehari hari kita merupakan kegiatan belajar. Dengan demikian kita dapat katakan, tidak ada ruang dan waktu dimana manusia dapat melepaskan dirinya dari kegiatan belajar, dan itu berarti pula bahwa belajar tidak perna dibatasi usia, tempat maupun waktu, karena perubahan yang menuntut terjadinya aktivitas belajar itu juga tidak pernah berhenti.

Menurut Suyanto (2005:133), Pembelajaran anak usia dini menggunakan prisip belajar, bermain, dan bernyanyi. Pembelajaran disusun sedemikaian rupa sehingga menyenangkan, gembira, dan demokratis sehingga menarik anak untuk terlibat dalam setiap kegiatan pembelajaran. Anak tidak duduk tenang mendengarkan cerama gurunya, tetapai meraka aktif berinteraksi dengan berbagai benda dan orang dilingkungannya, baik secara fisik maupun secara mental. Menurut Semiawan dalam Tatik (2016:50), pembelajaran pada anak usia dini hendaknya dilakukan dengan tujuan memberikan konsep-konsep dasar yang memiliki kebermaknaan bagi anak melalui pengelaman nyata yang memungkinkan anak untuk menunjukkan aktivitas dan rasa ingin tahu (curiousity) secara optimal.Berdasarkan teori diatas dapat disimpulkan pembelajaran anak usia di ni menggunakan konsep bermain sambil belajar agar proses pembelajaran menye nangkan bagi anak dan pembelajaran itu berlangsung seumur hidup.

\section{Model Pembelajaran}

Model pembelajaran pada umumnya memiliki beberapa pendapat, akan tetapi terdapat beberapa model-model pembelajaran yang bisa dilaksanakan oleh lembaga pendidikan anak usia dini. Model-model pembelajaran yang biasa dilaksanakan oleh lembaga-lembaga pendidikan anak usia dini menurut Bradekamp dkk, dalam Syamsuardi (2018:2) diantaramya:

a. Model Pembelajaran Klasikal

Model pembelajaran klasikal ini adalah model pembelajaran yang pertama diperkenalkan. Dalam model pembelajaran klasikal ini, guru merupakan pusat dari semua informasi maupun kegiatan, peserta didik hanya menjalaskan apa yang diperintahkan oleh guru sebagai pusat kegiatan pembelajaran. Model pembelajaran klasikal ini sangat penyaluran minat anak, sehingga anak tidak diberikan kebebasan berkplorasi, berkreaktifitas maupun menemukan jawabannya sendiri atas setiap pertnyaan mereka

b. Model Pmebelajaran Kelompok

Model pembelajaran kelompok dengan pengamanan, model pembelajaran ini membagi anak menjadi beberapa kelompok dengan kegiatan yang berbeda-beda, anak-anak yang telah menyelesaikan kegiatannya dapat melakukan kegiatan lainnya dikelompok yang lain. Apabila pada kelompok 
yang lain tersebut tidak bersedia tempat maka anak tersebut dapat melakukan kegiatan didalam tempat kegiatan pengaman, sampai tersedia tempat dikelompok yang lain.

c. Model Pembelajaran Sudut

Model pembelajaran sudut dengan pengaman, model pembelajaran ini menyediakan sudut-sudut kegiatan yang menjadi pusat kegiatan pembelajaran yang berdasrkan pada minat anak. Alat-alat dan media yang disediakan juga harus bervariasi mengingat minat anak yang beragam. Media dan alat-alat tersebut juga harus sering diganti dan diperbahrui disesuaikan dengan tema dan sub tema yang dibahas. Sudu-sudut kegiatan pada model pembelajaran ini dianataranya adalah sudut keluarga, sudut pembengunan, sudut kebudayaan, dan sudut ketuhanan.

d. Model Pembelajaran Area

Model pembelajaran area ini hampir sama dengan model pembelajaran sudut dengan pengaman yaitu model ini rancang untuk memenuhui kebutuhan dengan sesuai dengan minat dan karakteristik anak serta menghoramati keberagaman budaya dan didalamnya terdapat plihan-pilihan kegiatan pembelajaran. Area-area yang ada didalam model pembelajaran ini yaitu area music, area bahasa, area membaca dan menulis area drama, area pasir/air, area seni dan motorik.

Dari beberapa model pembelajaran dapat diartikan sebagai pengalaman belajar agar anak dapat mencapai tujuan belajar yang digunakan dalam kegiatan pembelajaran ini sendiri memiliki arti yang sama dengan pendekatan strategi ataupun model pembelajaran. Adapun beberapa model pembelajaran yang dilaksanakan di pendidikan anak usia dini yaitu: 1). Model pembelajaran klasikal 2). Model pembelajaran kelompok 3). Model pembelajaran sudut dan 4). Model pembelajaran area.

a. Pembelajaran Sentra

Menurut Gilley dan Gilley dalam Asmawati Dkk (2008:83), istilah sentra sering disebut juga dengan area, sudut kegiatan (actifiviy centre), sudut belajar (learning centre) atau sudut minat (interes centre). Sentra dapat diartikan sebagai permainan dan kegiatan yang disusun sedemikian rupa untuk memberikan semangat pada kegiatan-kegiatan pembelajaran secara khusus, yaitu yang berhubungan dengan kehidupan keluarga, musik, seni, sains, balok bangunan, dan seni berbahasa.

Sentra juga dapat diartikan sebagai zona area main anak yang dilengkapi dengan seperangkat alat main yang berfungsi sebagai pijakan lingk ungan yang diperlukan untuk mendukung perkembangan anak dalam 3 jenis main, yaitu main sensorimotor atau main fungsional, main peran, dan main pembangunan (Depdiknas, 2006). Menurut Fitriana (2018:26), sentra adalah zona atau area bermain anak yang dilengkapi dengan seperangkat alat main yang berfungsi sebagai pijakan lingkungan yang diperilaku untuk mendukung perkembangan anak dalam 3 (tiga) jenis main, yaitu main sensorimotor atau main fungsional, main peran dan main perkembangan.

Sentra adalah model pembelajaran yang memiliki ciri khas: learning by doing, dimana anak terlibat langsung dalam pembelajaran: learning by stimulatif, dimana pembelajaran anak diberikan sesui dengan tahapan perkembangannya; dan learning by modeling, dimana pembelajarannya menggunakan lebih berkembang. Yuliani dan Trias (2017:387).

Dari teori diatas sentra merupakan pembelajaran yang dalam proses pembelajarannya dalam lingkaran dimana anak-anak dengan posisi melingkar 
untuk memberikan pijakan-pijakan kepada anak yang dilakukan sebelum dan sesudah main.

b. Tujuan Pembelajaran Sentra

Tujuan pendekatan sentra Menurut Yuliana dalam Fitriana (2018:29), yang pertama adalah untuk merangsang seluruh aspek kecerdasan anak (multiple intellegent) melalui bermain terarah. Kedua yaitu menciptakan setting pembelajaran yang merangsang anak untuk saling aktif, kreaktif, terus berfikir dengan menggali pengalamannya sendiri (bukan sekedar mengikuti perintah, meniru, atau menghafal). Ketiga yaitu dilengkapi dengan standar operasional yang baku, yang berpusat di sentra-sentra kegiatan dan saat anak berada dalam lingkaran, sehingga mudah diikuti. Permainan-permainan yang dilakukan di sentra, diharapkan mampu meningkatkan seluruh aspek kecerdasan dan kreaktivitas serta kemampuan anak. Oleh karena itu melalui bermain anak dapat menikmati kegiatan belajar sehingga anak akan lebih mudah mengingat apa yang dipelajarinya. Tujuan sentra untuk meningkatkan pengalaman belajar kepada anak secara lebih mendalam dengan menggali pengalamannya sendiri untuk bereksplorasi dalam setiap sentranya.

c. Manfaat Pembelajaran Sentra

Menurut Asmawati dalam Gustin (2016:3), manfaat yang akan diperoleh melalui pembelajaran sentra khususnya bagi anak dianataranya yaitu meningkatkan kreaktivitas anak dengan memberikan kesempatan untuk bermain, bereksplorasi dan menemukan bahwa kegiatannya akan memabntunya dalam memecahkan masalah serta memahami konsep-konsep baru, termaksuk kemampuan koginitif dalam memahami konsep ukuran besar kecil.

Menurut Mayesky, dalam Asmawati dkk ( 2008:83), sentra mempunyai keterkaitan yang kuat dengan beberapa pandangan ahli pendidikan, seperti Pestalozzi yang percaya bahwa anak-anak belajar melalui interaksi langsung dengan anak lain dan lingkungannya; John Dewey dengan penekanannya pada "belajar sambil bekerja" serta Montessori dengan pemikirannya bahwa anak kecil belajar melalui tugas-tugas dan alat-alat belajar yang disiapkan dengan hati-hati.

Banyak manfaat yang akan diperoleh melalui penedekatan sentra, khususnya bagi anak, antara lain berikut ini. Asmawati dkk (2008:85).

a. Meningkatkan kreativitas anak dengan memberikan kesempatan padanya untuk bermain, bereksplorasi, dan menemukan bahwa kegiatannya akan membantunya dalam memecahkan masalah, mempelajari keahlian-keahlian dasar dan memahami konsep-konsep baru.

b. Melalui sentra, anak dapat memanipulasi objek dalam sentra-sentra yang disediakan, mengembangkan percakapan dan bermain peran serta belajar sesuai tingkatan dan langkah-langkah yang dia inginkan.

c. Mengembangkan keahlian belajar yang mandiri karena adanya prinsip kehendak sendiri (self directing) dan koreksi diri (self correcting) yang alamia terhadap berbagai alat di sentra kegiatan Tujuan Pembelajaran Sentra.

Dari beberapa manfaat sentra untuk mengembangkan keahlian belajar anak dan meningkatkan kreaktifitas anak dengan bereksplorasi. Melalui sentra anak dapat bermain dan belajar sesuai tingkatnya.

a. Macam-Macam Sentra

1) Sentra Imtaq

Aktivitas pada sentra imtaq ini lebih fokus pada kegiatan keagamaan seperti, pembecaan iqra, doa-doa, membedakan benda ciptaan 
Tuhan dengan ciptaan manusia, ahlak yang baik dan lain sebagainya Fatmawati dan Muhammad (2019:30).

2) Sentra Bahan Alam

Sentra bahan alam adalah tempat anak melakukan kegiatan dengan berbagai alat yang tepat sesuai dengan kebutuhan anak yang terdiri dari alat/bahan kering dan alat/bahan yang menggunakan air Sujjono dan Sujiono, dalam Pratiwi (2010:186).

3) Sentra Seni

Sentra seni adalah sentra yang kegiatannya terdiri dari keterampila $\mathrm{n}$ tangan seperti: melipat, menggunting, merekat, prakarya, melukis, dan $\mathrm{p}$ ertukangan. Sentra ini dimaksudkan untuk mengembangkan keterampilan dan kreaktivitas anak. Sentra seni merupakan hal yang sangat penting men gembangkan keterampilan seni anak. Kegiatan seni juga memberi sumber pada perkembangan anak lainnya. Hermansyah (2019:116)

4) Sentra Main Peran

Sentra main peran adalah sentra yang mengalirkan materi atau knowledge pada anak melalui peran. Alat atau media main atau media main yang dipergunakan berukuran besar sesuai dengan ukuran yang dipakai dalam kehidupan sesungguhnya .di sentra ini, anak mengekspresikan ideidenya dengan gesture memerankan sesorang atau sesuatu dengan atau tanpa objek.

Main peran menurut Erik Erikson dalam Tamin (2010:46) adalah suatu jalan bagi anak untuk mengembangkan pengendalian dirinya terdapat keinginannya dan selanjutnya anak menghadapi serangan dari luar terhadap egonya. Secara terhadap anak mempelajari tuntutan dari luar yang datang setiap hari.

5) Sentra Persiapan

Sentra persiapan adalah area anak untuk meningkatkan kemampuan kognitif, pengetahuan, dan sains sederhana. Pada area ini anak bermain dengan angka, menghitung, menjumlah, mengurang, percobaan ilmia sederhana seperti mengelompokkan warna, mencampur warna, bermain geometri, mencocokan dan lain sebagainya. Nur Hamzah ( 2016:123)

6) Sentra Balok

Sentra beberapa yang dapat disediakan dan digunakan dan kegunaan dalam proses pembelajaran, salah satunya adalah sentra balok. Rahaju dalam Rohita (2019:4) menyatakan bahwa sentra balok berisi berbagai macam block (balok) dalam berbagai bentuk, ukuran, warna, dan tekstur. Di dalam sentra balok, anak belajar banyak hal dengan cara menyusun atau menggunakan balok, mengembangkan kemampuan logika matematika atau berhitung permulaan, kemampuan berpikir dan memecahkan maslah.

b. Pengertian Sentra Balok

Menurut Nielsen (2006:49), sentra balok merupakan sentra yang didalamnya terdapat beragam balok unit yang terdiri dari berbagai bentuk dan ukuran disertai aksesoris pendukung serta alat main peran Zukhairina, dalam Harlistyarintica, (2019:208), sentra balok memberikan kesempatan bagi anak untuk berimazinasi, berkomunikasi, dan berkerjasama. Menurut Nielsen, dalam Harlistyarintica, (2019:209), aspek perkembangan dan kecerdasan jamak anak akan berkembang secara optimal. Salah satu sentra pembelajaran yang menjadi kandidat utama anak yaitu pembelajaran di sentra balok. 
Balok adalah suatu alat permainan konstruksi terstruktur yang bertujuan untuk menyelesaikan permasalahan suatu bangunan balok, mengembangkan kemampuan berbahasa ekspresif, meningkatkan kerjasama, dan untuk mengungkapkan representasi simbolik dan ide-ide kreatif sewaktu bermain balok. Balok sebagai alat bermain yang bersifat terstruktur, hal ini karena dalam penggunaannya, balok dikontrol berdasarkan bentuk dari bahan yang akan dimainkan Isabell dalam Nurani (2016).

Dari beberapa teori di atas dapat disimpulkan. Sentra balok salah satu sentra yang disediakan untuk pendidikan anak usia dini. Melalui sentra balok anak dapat mengembangkan imajinasi, menghargai pendapat orang lain, mengenal bentuk ukuran, konsep ruang, klasifikasi, kerapian, ketelitian, bahasa dan kreaktivitas. Bermain balok dapat dikaitkan dengna main peran mikro dan bangunan anak digunakan untuk bermain peran.

Dalam pembelajaran sentra balok dapat mengembangkan 6 aspek perkembangan anak yaitu:

1) nilai agama moral dimana pembelajaran sentra balok anak belajar saling menghargai, berbagi, misalnya, jika teman kekurangan balok tentu, anak diminta untuk mau membagi balok dengan teman sebayanya.

2) Fisik motorik anak juga menggunakan jari jemarinya dalam menyusun balok di antara otot tangan dan mata. Ketika anak menggenggam, menyusun dan merangkai balok, saat itulah motorik bekerja.

3) Kognitif anak dapat berimajinasi, bereksplorasi, dan kreaktivitas anak membentuk atau merangkai balok menjadi suatu benda, anak dapat mengembangkan pengetahuannya anak berpikir untuk menciptakan halhal baru.

4) Sosial emosional dapat dilihat dari interaksi anak dengan teman sebaya dan melatih kesabaran, ketelitian untuk mampu menyusun balok hingga menjadi bentuk yang anak inginkan.

5) Bahasa dapat dilihat dari bagaimana anak berkomunikasi dengan teman sebaya dan guru selama pembelajaran.

6) Seni adalah salah satu kreativitas menyusun balok menjadi bentuk-bentuk benda yang mengandung unsur keindahan dan mampu membangkitkan perasaan anak maupun orang lain.

c. Tujuan Sentra Balok

Menurut Nurani (2016:2), tujuan dari kegiatan sentra balok yaitu:

1) Mengembangkan kemampuan berbahasa ekpresif

2) melatihkerja sama anak

3) mengungkapkan respresentasi simbolik dan ide-ide kreaktif sewaktu bermain balok

4) mengeksplorasi segala kemampuan yang ada dalam dirinya melalui berbagai stimulasi yang diberikan guru maupun orang tua

5) anak dapat menyelesaikan permasalahan (yang berhubungan dengan suatu bangunan balok pada saat bermain)

6) mengembangkan perkembangan fisik anak (koordinasi mata, tangan, dan kaki)

7) dapat melatih motorik anak

8) dapat mengembangkan perkembangan sosial emosional pada anak (mandiri, kerjasama, dan saling menghargai)

9) pemahaman tentang sains (keseimbangan, konsep ruang, perbandingan ukuran, dan gravitasi)

Dari beberapa tujuan sentra balok, sentra balok dapat mengemabngkan kemampuan anak untuk melatih kerja sama dan 
mengungkapkan ide-ide yang kreaktif saat bermain balok. Sentra balok juga dapat mengembangkan fisik anak, social emosional. Anak dapat mengeksplorasi segala kemampuan anak melalui stimulasi yang diberikan guru maupun orang tua.

d. Manfaat Sentra balok

Menurut Mukhtar Latif dkk dalam Pertiwi (2020:30), mengungkapkan bahwa manfaat bermain balok dapat mengembangkan sebagai berikut:

1) Keterampilan hubungan dengan teman sebaya.

Anak bermain berkelompok selain itu anak juga mengatur rencana tentang apa yang akan dibuat tentunya saling tolong nenolong dalam menyediakan alat main yang akan di gunakan.

2) Keterampilan komunikasi.

Anak saling menyepakati pekerjaan, berkomunikasi setaip ada saran atau bantuan, berbicara dengan menggunakan dalam hal ini akan terbangun sikap mengahrgai antara sesama.

3) Kekuatan dan koordinasi motorik halus dan kasar.

Anak menggunakan jari jemarinya dalam menyusun balok membentuk suatu bangun yang anak inginkan.

4) Konsep matematika dan geometri.

Dalam bermain susun balok akan ditemukan dengan konsep seperti bentuk lingkaran, silindirs, segi empat, segitiga.

5) Pemikiran simbolik.

Anak bermain dengan cara menuangkan pikiran yang penuh mereka lihat dengan menggunakan balok.

Dari beberapa manfaat disimpulkan bahwa manfaat dari sentra balok antara lain dapat belajar mengenai konsep warna, bentuk, ukuran dan keseimbangan anak dapat mengembangkan imajinasi, melatih kesabaran anak, melatih bersosialisasi anak, mengemabngkan kemampuan spasial dan matematika anak.

e. Pijakan-Pijakan Di Sentra Balok

Menurut Fatchuriyah (2014:23), di sentra balok, sebelum kegiatan guru memeberikan pijakan-pijakan dukungan, bantuan, bimbingan, arahan, dan penjelasan harapan-harapannya terhadap anak yang diberikan guru kepada anak. Pijakan-pijakan di sentra balok, antara lain:

1) Pijakan Lingkungan Sebelum Main

a) Mengelola awal lingkungan main dengan bahan-bahan yang cukup. Meliputi jumblah balok yang mencukupi, satu anak idealnya membutuhkan 100 buah balok. Balok diklasfikasikan di rak dan diberi nama atau tulisan. Disediakan alas balok dan untuk alas barmain balok dan aksesoris bermain balok untuk ekplorasi dan pengembangan main balok unit.

b) Merencanakan isensitas dan densitas main. Intensitas bermain adalah sejumblah waktu yang dibutuhkan anak untuk pengelaman dalam tiga jenis main sepanjang hari dan tahun. Contoh anak-anak diperbolehkan untuk memilih dari serangkaian kegiatan main setiap hari yang menyediakan kesempatan untuk terlibat dalam main peran, pembangunan dan sensorimotor. Anak boleh ekplorasi dengan balok main sensorimotor.

c) Memiliki berbagai bahan yang mendukung tiga jenis main sensorimotor, pembengunan dan main peran balok, lego, dos-dos bekas mendukung main pembengunan, aksesoris main balok dapat 
mendukung main peran mikro, dan kedua bahan tersebut dapat dieksplorasi anak untuk mendukung main sensorimotor.

d) Menata kesempatan main untuk mendukung hubungan sosial yang positif, dua atau tiga anak membengun satu bangunan akan mendukung hubungan sosial yang positif.

2) Pijakan sebelum main

a) Membaca buku yang berkaitan dengan pengalaman atau mengundang nara sumber. Buku yang berkaitan dengan pengalaman atau mengundang nara sumber. Buku yang dibacakan yang sesuai dengan tema dan memberi ide bangunan yang akan dibangun.

b) Menggabungkan kosa kata baru dan menunjukan konsep yang mendukung standar kinerja. Kosa kata baru yang ada di buku, kosa kata bentuk balok dan yang terkait dengan tema dapat di ulang-ulang.

c) Memberikan gagasan bagaimana menggunakan bahan-bahan. Gagasan yang diberikan adalah "bentuk balok" dan "tahapan bermain balok".

d) Mendiskusikan aturan dan harapan untuk pengalaman main, seperti : anak-anak membangun dengan balok, tetapi tidak melemparnya, anakanak tetap membangun di atas alas, setelah selsai anak-anak mengembalikan ke rak balok, anak-anak hanya mengambil balok yang dibutuhkan,

e) Menjelaskan rangkaian waktu main. Waktu bermain balok bisa didiskusikan dengan anak, berapa lama mereka membangun dari bangunan dari balok unit, manambah aksesoris balok, menggambar bangunan yang dibuat, membuat tandah atau tulisan pada bangunan yang dibuat, menceritakan bangunan yang dibuat merapikan balok.

f) Mengelola anak untuk keberhasilan hubungan sosial. Keberhasilan hubungan sosial dapat dilakukan dengan membangun bersama-sama atau kelompok 2-3 anak, alas balok digabung untuk 2-3 anak, anak mengambil balok dari rak yang sama sehingga butuh toleransi, anak memberikan bersama-sama.

3) Pijakan saat main balok

a) Memberikan anak waktu untuk mengelolah dan meneliti pengelaman main mereka. Anak mempunyai kesempatan cukup untuk main balok, waktunya untuk cukup mengelola, meneliti dan menemukan konsep. Ada cukup waktu untuk bercerita sampai dengan membereskan .

b) Mencotohkan komunikasai yang tepat. Saat main balok anak berkomunikasi dengan anak lain dan guru misalnya bercerita tentang bangunannya. Pada saat bercerita dengan muncul kata-kata yang tidak tepat susunan kalimatnya, guru cakup mengulang kalimat yang benar.

c) Meningkatkan kesempatan sosialisasi melalui dukungan hubungan teman sebaya. Dalam satu kelas ada beberapa anak yang bermain balok main parallel dalam situasi ini akan terjadi komunikasi anak antar anak.

d) Mengamati dan mendokumentasikan perkembangan dan kemajuan anak.

4) Pijakan sesudah main balok

a) Mendukung anak untuk mengingat kembali pengalaman mainnya dan saling menceritakan pengalaman mainnya. Pada saat recall, anak secara bergiliran dapat menceritakan bangunan yang sudah dibangunnya, balok-balok yang digunakan dan aksesoris yang digunakan 
b) Menggunakan waktu membereskan sebagai pengelaman yang belajar positif.

Dari beberapa prosedur dalam pelaksanaan sentra balok, yaitu pijakan llingkungan main, pijakan sebelum main, pijakan saat main, dan pijakan setelah main. Pijakan tersebut dilakukan secara berurutan yang dimulai dengan pijakan lingkungan, pijakan sebelum main, pijakan saat main dan pijakan setelah main.

Penelitian yang dilakukan oleh Dhuriyatun Nasichah dengan judul "Imp lementasi Model Pembelajaran Sentra Balok Anak Kelompok B Di TK Khadijah Pendegiling Surabaya"berdasarkan hasil penelitian menunjukan setiap anak memiliki nilai antara 62,5-87,5\% yang dominan dari tujuh komponen sentra balok. Melalui implementasi model pembelajaran sentra balok guru memberikan tujuh komponen tersebut untuk menumbuhkan perkembangan anak kelompok B.

Penelitian yang dilakukan oleh Yora Harlistyarintica dengan judul “ Pelaksanaan Pembelajaran Sentra Balok Pada Anak Usia 5-6 Tahun Di Tk Masjid Syuhada Yogyakarta". Berdasarkan hasil penelitian dan pembahasan dapat disimpulkan bahwa proses pelaksanaan pembelajaran sentra balok pada anak usia 5-6 tahun di TK Masjid Syuhada Yokyakarta dimulai dari perencanaan hingga evaluasi pembelajaran.

Perencanaan pembelajaran sentra balok pada anak usia 5-6 tahun yaitu dengan membuat prosem, RPPM, dan RPPH. Pelaksanaan pembelajaran sentra balok terdiri dari empat pijakan main yaitu pijakan lingkungan main, pijakan sebelum main, pijakan selama main, dan pijakan setelah main yang dalam pelaksanaannya dilakukan sesuai dengan RPPH yang telah dibuat. Evaluasi pembelajaran sentra balok dengan menilai perkembangan anak setiap harinya. Instrument penilaian menggunakan catatan anekdot, anlisis hasil karya anak, penilaian harian, penilaian mingguan dan bulanan, raport.

Penelitian yang dilakukan oleh Gustin Mar'atus Sholikhah "Model Pembelajaran Sentra Balok Modifikasi Terhadap Kemampuan Kognitif Memahami Konsep Ukuran Pada Anak Autis Di TK". Berdasarkan hasil penelitian dengan diberikan model pembelajaran sentra balok modifikasi dapat diperoleh $\mathrm{T}$ hitung $=\mathrm{T}$ tabel $=2(0 \leq 2)$. Hal ini membuktikan bahwa terdapat pengaruh model pembelajaran sentra balok modifikasi terhadap kemampuan kognitif memahami konsep ukuran besar-kecil anak autis di TK Mentasari School Sidarjo. Selain itu, menunjukan bahwa melalui model pembelajaran sentra balok modifikasi anak mendapatkan pengelaman belajar yang menyenangkan, menemukan hal-hal baru yang dapat meningkatkan perkembangan kognitif termasuk kemampuan dalam memahami konsep besar kecil.

Berdasarkan hasil penelitian relevan di atas maka disimpulkan bahwa pembelajaran sentra balok. Memiliki pencapaian perkembangan yang baik. Ak tifitas anak meningkat setelah pelaksanaan kegiatan sentra balok anak dapat berimajinasi dan bereksplorasi untuk melatih aspek-aspek perkembangan dan menemukan hal-hal baru.

\section{Simpulan}

Pembelajaran sentra balok aktifitas anak dapat meningkatkan 6 aspek yakni nilai agama moral, fisk motorik, kognitif, sosial emosional, bahasa dan seni. Sentra balok terdapat beberapa pijakan yaitu: 1) Pijakan lingkungan sebelum main 2) Pijakan sebelum main 3) pijakan saat main balok 4) Pijakan sesudah main. Sentra balok anak dapat diajarkan untuk bekerja sama secara sederhana dan membagi tugas. Bekerja 
sama baik secara spontan ataupun dengan guru untuk melaukukan tugas masingmasing di tiap kelompok. Sentra balok anak dapat belajar mengenal konsep, belajar mengembangkan imajinasi, melatih kesabaran, secara sosial anak belajar berbagi, dan mengembangkan rasa percaya diri anak. Pada pelaksanaan pembelajaran sentra balok guru pada saat mempersiapkan sentra balok dan menata kelas media pembelajaran hanya berupa balok. Guru menentukan balok mana yang akan dibuka dan boleh digunakan. Kegiatan selanjutnya adalah memberitahu macam-macam bentuk balok dan cara menyusun balok. Anak mengambil balok dari lemari dari tempat kegiatan bermain dan anak dapat menyusun berbagai bentuk balok sesuai yang dinginkan. Anak juga berbagi balok dengan temannya dan anak dapat bekerja sama dengan temannya dalam penyusunan balok anak menyusun balok sesuai dengan imajinasinya mencari jenis balok, serta alat pendukung permainan yang sesuai dengan kebutuhan anak.

\section{DAFTAR PUSTAKA}

Aunurrahman. 2012. Belajar Dan Pembelajaran. Bandung. Penerbit Alfabeta

Ariyanti, Tatik. 2016. Pentingnya pendidikan anak usia dini bagi tumbuh kembang anak. Jurnal Dinamika Pendidikan Dasar. Vo 8, No1 1, Maret 2016:50-58.

Azhari Adi, Mukti. 2017 Aplikasi Pembelajaran Sentra Persiapan Untuk Pendidikan Anak Usia Dini Berbasis Android. Jurnal Dinamika Iformatika. (2017) 287

Eka Fitriana. 2018. Model Pembelajaran Di Taman Kanak-Kanak Islam Terpadu (Tt) QurrotaA'yubandar lampung. (Skripsi) Universitas Lampung. Fakultas Keguruan Dan Ilmu Pendidikan.

Fatmawati Dan Latif, Abdul Muhammad. 2019. Implementasi Model Pembelajaran Sentra Di TK AmalInsani Yogyakarta. Jurnal IlmuTumbuh Kembang Anak Usia Dini. Volume 4 No 2. Juni 2019.

Fitriani, Riskia Dan Rohita. 2019. Penanaman Kemandirian Anak Melalui Pembelajaran Di Sentra Balok. Jurnal Al-Azhar Indonesia Seri Humaniora.Vo 5. No.1.Maret 2019.

Fatchuriyah, Azimatul Risa, 2014. Peningkatan Kemampuan Komunikasi Usia 3-4 Tahun Melalui Permainan Balok Unit Di Sentra Balok. Skripsi Universitas Negeri Se marang: Fakultas Ilmu Pendidikan:

Hermansyah. 2019. Pembelajaran Melalui Sentra Seni Dalam Mengembangkan Kreaktifitas Anak Usia Dini. Jurnal. Vo 6. Nomor 1. April 2019.

Hamzah, Nur. 2016. Pelaksanaan Pembelajaran BCCT Bagi Anak Usia Dini; Study Pelaksanaan BCCT Di Tk Islam Mujahidin Pontianak. Jurnal Pemikiran Pendidikan Islam. Vo. 10 No 2 (2016) 119-132.

Harlistyarintica, Yora . 2019. Pelaksanaan Pembelajaran Sentra Balok Pada Anak Usia 5-6 Tahun Di TK MasjidS yuhada Yogyakarta. Jurnal Pendidikan Anak Usia Dini.

Nasichah, Dhuriyatun. 2017. Implementasi model pembelajaran sentra balok anak kelompok B di TK khadijah pedegiling Surabaya. Jurnal PAUD Teratai. Vo 3.

Nuarani Dan Yuliani. 2016. Sentra Balok Tema: Pertokoan. Jakarta: Indocam Prima

Nurani, Yuliani Dan Mayangasr, Trias i. 2017. Pengembangan Model Kegiatan Sentra Bermain Dalam Mengembangkan Kraktivitas Anak Usia Dini. Jurnal Pendidikan Anak Usia dini. Vo 11 Edisi 2, November 2017.

Nurul, Zahriani Dan Reiska, Primanisa. 2020. Tindak Lanjut Hasil AsesmenTerhadap Pelaksanaan Pembelajaran Anak UsiaDini Di Taman Kanak-Kanak (TK): Jurnal Pendidikan Raudhatul Athfal. 
Pertiwi, Hana Puput. 2020. Implementasai Pembelajaran Sentra Balok Dalam Mengembang kan Motorik Halus Anak Usia 4-5 Tahun Di Tk Aisyiyah Pucangan 1 Kartasura. Skripisi. Fakultas Ilmu Tarbiyah Insitut Agama Islam Negeri Surabaya.

Rika, Ajeng Dan Nopiana. 2017. Pengaruh Model Pembelajaran Sentra Bahan Alam Terhadap Kemampuan Sains Dan Berbicar anak Kelompok B Taman Kanak-Kanak. Jurnal Pendidikan Anak Usia Dini Vo. 11 Edisi April 2017.

Samad, Farida Dan Alhadad, Bujuna. (2016, november 30). jurnal pendidikan usia dini. implementasi metode beyond center and circle time (bcct) dalam upaya penaman nila-nilai agama islam di kelompok b taman kanak-kanak kalifah kota ternate, 10(2), 234-235. Retrieved november 30, 2016, from

https://media.neliti.com/media/publications/11852-id-none.pdf

Sholikhah, Mar'atus Gustin. 2016. Model Pembelajaran Sentra Balok Modifikasi Terhadap Kemampuan Kognitif Memahami Konser Ukuran Pada Anak Autis Di TK. Jurnal pendidikan khusus.

Slamet, Suyanto. 2005. Konsep Dasar Pendidikan Anak Usia Dini. Jakarta: Direktor Pembina an Pendidikan Tenaga Kependidikan Dan Ketenagaaan Perguruan Tinggi.

Syamsuardi Dan Hajerah. 2018. Penggunaan model pembelajaran pada taman kanakkanak kota Makassar. Jurnal CARE 5(2).

Tamin, Wismiarti. 2010. Pendidikan Karakter Melalui Metode Sentra. Jurnal Akrab. Vo 1 Edisi 3 September 2010 Tamin. 